\title{
Lymphokine-Activated Natural Killer Cell
}

National Cancer Institute

\section{Source}

National Cancer Institute. Lymphokine-Activated Natural Killer Cell. NCI Thesaurus. Code C33041.

A natural killer cell, activated by a soluble cytokine released by a lymphocyte in response to an antigen. It is important in immune response. 